\title{
HUBUNGAN ANTARA KADAR ENZIM GLUTATION REDUKTASE DENGAN DERAJAT KEKERUHAN INTI LENSA
}

\section{THE CORRELATION BETWEEN THE LEVEL OF GLUTATHIONE REDUCTASE AND THE SEVERITY OF NUCLEAR CATARACT}

\author{
T Budi Sulistya*, Debby Shintiya Dewi* ${ }^{*}$.Hidayat Suyuti*, Sumarno*** \\ * Laboratorium IImu Penyakit Mata Fakultas Kedokteran Unibraw / RSU dr. Saiful Anwar Malang \\ ** Laboratorium Biokimia Fakultas Kedokteran Unibraw Malang \\ ${ }^{* * *}$ Laboratorium Mikrobiologi Fakultas Kedokteran Unibraw Malang
}

\begin{abstract}
The aim of this study was to determine the correlation between the level of glutathione reductase [GR] in relation with the severity of nuclear cataract and the increase of age. An analytic cross sectional observasional study of nuclear cataract patient seen at Saiful Anwar Hospital and Mass Cataract Surgery performed by Perdami Malang was carried out. Patients were classified into 3 groups based on age and 4 groups based on severity of nuclear cataract. The samples were taken by consecutive sampling and were operated on visual indication. The extracted lens were examined for [GR]. The laboratory findings of [GR] were compared with the severity of senile cataract. The data were analyzed with one way ANOVA. Confidence limit was set at $95 \%$. A total of 55 patients were included with the sample size in $40-50$ age group less than estimation. The [GR] were found to be significanfly lower in the older age $(p=0,01)$ and the more severe cataract groups $(p=0,00)$. The $[G R]$ were also found to be significantly decreased with the increase of cataract severity in $40-50$ age group $(p=0,00), 50-60$ age group $(p=0,01)$ and $>60$ age group $(p=0,00)$. In the grade 2 cataract, there were no significant difference of [GR] between age group $(p=0.22)$. This also occured in grade $3(p=0.23)$ while in the grade 4 , there were significant difference between age group $(p=0.01)$. This also occured in grade $5(p=0.06)$. Pearson correlation test showed that there was a strong correlation between $[G R]$ and increase of age $(r=0.979)$ and cataract severity $(r=0.969)$. But in the same cataract grade, the increase of age was not always associated with low [GR] $r=0.413$,for grade 2, $r=0.876$ for grade 4 and $r=0.731$ for grade 5). The conclusion is the increase of age and severity of nuclear cataract In senile cataract, are associated with low [GR]. This association was also found, with the increase of cataract severity in the same age group. However, in the same cataract grade the increase of age is not always associated with a low [GR]
\end{abstract}

Key words: senile cataract - glutathione reductase - nuclear cataract grade - age

\section{PENDAHULUAN}

Katarak senilis (Age-related Cataract) merupakan salah satu problem utama kesehatan masyarakat di dunia $(1,2)$. Di negara sedang berkembang, dimana fasilitas kesehatan masih terbatas, terutama fasilitas operasi, buta katarak mencapai hampir setengah dari semua kebutaan (1,3-4). Angka kebutaan didunia $0,1-0,4 \%$ pada negara maju, sedang di negara sedang berkembang tercatat 0,5 $1,5 \%$ dengan sebab utama katarak (5,6). Di Indonesia menurut Survei Kesehatan Indra Penglihatan dan Pendengaran Tahun 1993-1996 angka kebutaan 1,5\% dengan penyebab utama katarak $(0,78 \%)(7,8)$.

Faktor resiko terjadinya katarak senilis sangat beragam. Faktor personal seperti usia, jenis kelamin, etnis dan keturunan sangat penting. Saat ini penelitian dilakukan pada interaksi antara genetik dan lingkungan yang mempengaruhi genetik tersebut.

Jurnal Kedokteran Brawijaya, Vol. XXII, No.1, April 2006 Korespondensi: T. Budi S; Lab. IImu Penyakit Mata Fakultas Kedokteran Unibraw/RSU dr. Saiful Anwar Malang
Faktor lingkungan sangat penting dalam kataraktogenesis. Faktor-faktor tersebut sering terjadi pada masyarakat misal merokok dan paparan sinar ultraviolet. Merokok dapat meningkatkan kejadian katarak inti dan sub kapsular posterior ( PSC ), sedang katarak kortikal dan inti berhubungan dengan paparan lama sinar ultraviolet $(9,10)$.

Katarak adalah keadaan dimana lensa menjadi keruh atau kehilangan transparansinya. Supaya mata dapat berfungsi dengan baik memerlukan lensa yang bening / transparan dan lentur / elastis. Lensa berfungsi sebagai media refraksi, yang berperan secara pasif dalam proses akomodasi sehingga sinar yang melalui kornea dan humor akuos dapat difokuskan di retina dan menghasilkan tajam penglihatan yang baik. Transparansi lensa ini dipertahankan oleh keseragaman serat, keseragaman distribusi dan komposisi protein kristalin dalam lensa $(5,11)$.

Dengan pertambahan usia, sifat tranparansi lensa ini dapat menurun oleh karena lensa mengalami perubahan ikatan struktur protein dan penguningan inti, sehingga terjadi peningkatan kekeruhan inti lensa. Telah diketahui 40 
tentang adanya penyaring ultraviolet yang berperan penting dalam terjadinya pewarnaan lensa manusia normal dan pembentukan katarak. Struktur tersebut adalah L-3Hydroxykynurenine O-B-D- glucoside (3OHKG) yang berikatan dengan kristalin. Ikatan tersebut menghasilkan komponen yang secara karakteristik ditemukan pada lensa katarak senilis $(11,12-8)$.

Dalam kaitan dengan proses penyaring ultraviolet (UV filter) ini, terkait pula peran glutation teroksidasi dan tereduksi. Glutation tereduksi (GSH) akan mengikat penyaring ultraviolet $(3 \mathrm{OHKG})$ yang terdeaminasi supaya tidak berikatan dengan protein kristalin sehingga tidak terjadi pewarnaan dan kekeruhan lensa. Kadar Glutation tereduksi (GSH) ini mulai usia 40 tahun semakin menurun dengan pertambahan usia dan hal ini semakin meningkatkan ikatan 3OHKG dengan kristalin. Ikatan 3OHKG dengan kristalin ini tidak didifusikan keluar lensa sehingga akan semakin menumpuk dalam lensa, terutama inti, menyebabkan terjadinya halangan difusi antara kortek dan inti yang pada proses selanjutnya akan semakin mengurangi kadar Glutation tereduksi (GSH). Ketersediaan Glutation tereduksi (GSH) sendiri harus melalui proses reaksi yang dikatalisasi oleh enzim Glutation reduktase (GR) yang merubah glutation teroksidasi (GSSG) menjadi Glutation tereduksi (GSH) $(11,13,15,16)$.

Telah dikemukakan bahwa konsentrasi Glutation teroksidasi (GSSG) pada inti lensa mulai usia 20 tahun meningkat secara nyata dengan pertambahan usia, tetapi kadar Glutation tereduksi (GSH) menurun sangat rendah. Padahal pada kondisi normal GSSG dapat dirubah menjadi GSH dengan proses katalisasi oleh enzim Glutation reduktase(GR). Ketersediaan $\mathrm{GSH}$ yang mencukupi akan mencegah ikatan penyaring ultraviolet 3OHKG dengan protein kristalin yang dapat menyebabkan kekeruhan inti lensa. Konsentrasi GSH inti lensa yang rendah menyebabkan penyaring ultraviolet berikatan dengan kristalin, sehingga terjadi pewarnaan dan rusaknya struktur kristalin. Kerusahan hebat pada kristalin juga terjadi bila kadar GSH turun hingga $1 \mathrm{mM}$, menyebabkan awal terjadinya katarak inti. ) $(11,13,15,16)$.

Menurut Bova et al (2001) Konsentrasi Glutation teroksidasi (GSSG ) pada inti lensa meningkat secara nyata dengan pertambahan usia. Konsentrasi terendah didapatkan pada usia kurang dari 20 tahun yaitu antara 0.1$0,3 \mathrm{mM}$, sedang pada dekade ke-8 kehidupan menjadi 0,5$0,6 \mathrm{mM}$. Sedangkan kadar GSH inti $4,5 \mathrm{mM}$ pada usia 20 tahun dan menurun $7 \%$ perdekade menjadi $3 \mathrm{mM}$ pada dekade ke 9 (13).

Secara teori anti oksidan dapat melindungi protein dan membran dari paparan oksidatif yang mencegah kataraktogenesis. Berbagai diet dan suplemen dengan berbagai efek antioksidan telah diteliti, tetapi hasilnya belum memuaskan (10).
Berdasarkan fakta-fakta diatas, penelitian ini dikerjakan untuk mengetahui apakah pada katarak senilis meningkatnya kelompok usia berhubungan dengan rendahnya kadar enzim glutation reduktase dan apakah pada katarak senilis meningkatnya derajat kekeruhan inti lensa berhubungan dengan rendahnya kadar enzim glutation reduktase. Selain hal tersebut diatas, penulis juga ingin mengetahui apakah pada katarak senilis dengan kelompok usia yang sama, meningkatnya derajat kekeruhan inti lensa berhubungan dengan rendahnya kadar enzim glutation reduktase dan apakah pada katarak senilis dengan derajat kekeruhan inti lensa yang sama, meningkatnya kelompok usia berhubungan dengan rendahnya kadar enzim glutation reduktase. Selanjutnya diharapkan dengan penelitian ini dapat diketahui enzim yang berperan dalam mekanisme timbulnya katarak dan dapat mencegah atau memperlambat terjadinya katarak senilis, memperkaya kasanah ilmu pengetahuan dan menjadi dasar penelitian selanjutnya yang berkaitan.

\section{BAHAN DAN CARA}

Penelitian ini merupakan penelitian analitik cross sectional yang dilakukan di RS dr. Saiful Anwar Malang, safari katarak di Puskesmas binaan Perdami cabang Malang dan Laboratorium Biomedik FK Unibraw. Sampel penelitian diambil secara consecutive sampling dari penderita operasi ekstraksi katarak atas indikasi visual di Bagian Mata RSSA Malang dan safari katarak di Puskesmas binaan Perdami cabang Malang pada Agustus 2004-Pebruari 2006

Pemeriksaan derajat kekeruhan inti lensa dengan alat biomikroskop Slit-lamp ${ }^{22}$ dinilai pewarnaan pada inti sesuai klasifikasi Buratto (8).

Pemeriksaan Glutation reduktase bahan penelitian inti lensa dengan cara sampel disimpan dalam tempat tertutup steril dan disimpan dalam keadaan membeku pada suhu $-20^{\circ} \mathrm{C}$. Sampel dikelompokkan sesuai kelompok usia dan derajat kekeruhan kataraknya sebelum operasi. Pada pemeriksaan dilakukan homogenisasi dengan $1 \mathrm{ml}$ larutan dapar $0,1 \mathrm{M}$ Tris/ $\mathrm{HCl} \mathrm{pH} 7,2$, yang mengandung $154 \mathrm{mM}$ $\mathrm{NaCl}$ dalam suhu $4^{\circ} \mathrm{C}$. Selanjutnya dilakukan pemusingan dengan $3.000 \times$ g selama 20 menit dalam $4^{\circ} \mathrm{C}$, bagian larutan ( supernatant) nya dipisahkan untuk langsung dianalisa atau kembali dibekukan pada $-20^{\circ} \mathrm{C}$.

Kadar glutation reduktase diukur menurut prosedur Carlberg dan Mannervik. Sebanyak $50 \mu \mathrm{L}$ hasil larutan homogenate lensa ditambahkan kedalam $1,55 \mathrm{~mL}$ campuran larutan yang terdiri dari $100 \mathrm{mM}$ buffer $\mathrm{KPO}_{4}(\mathrm{pH}$ 8,0), 1,0 mM EDTA, 1,0 mM glutation teroksidasi (GSSG) dan 0,2 mM NADPH. dan penurunan densitas optical dari larutan ini dicatat dengan menggunakan spektrofotometer ( Spektrofotometer fluorescen merk Simatsu 2000 ) pada panjang gelombang $340 \mathrm{~nm}$ yang direkam pada suhu $25^{\circ}$ 
C. Satu unit enzim didefinisikan sebagai $1 \mu \mathrm{mol} / \mathrm{min}$ NADPH teroksidasi pada $25^{\circ} \mathrm{C}(4,12)$.

Kriteria inklusi pada penelitian ini penderita laki-laki dan wanita, berusia lebih dari 40 tahun, penderita dengan

kekeruhan inti lensa berbagai derajat, setuju dan menandatangani Informed consent dilakukan operasi katarak ekstraksi atas indikasi visual.

Kriteria eksklusi adalah bila ekstrak sampel lensa yang didapat setelah proses tidak memenuhi kriteria, katarak komplikata, katarak dengan komplikasi, disertai Diabetes mellitus atau setelah regulasi Diabetes mellitus.

Definisi Operasional Katarak adalah kekeruhan lensa dengan derajat kekeruhan menurut Buratto (8)

Derajat 1: inti transparan atau abu muda, umumnya kekeruhan pada kortek atau subkapsular, seperti pada katarak presenilis.

Derajat 2: katarak inti abu muda atau kuning-abu. Terdapat pada katarak presenilis, terutama katarak subkapsular posterior.

Derajat 3: khas pada katarak senilis. Berwarna kuning jika katarak inti predominan pada bagian perifer lensa. Dapat berwarna abu pada katarak dengan komponen kortikokapsular pada pasien > 60-65 tahun.

Derajat 4: berwarna kuning-coklat dan terdapatpada katarak senilis lanjut dengan bagian inti besar.

Derajat 5: inti berwarna coklat-hitam. Merupakan katarak senilis yang sudah sangat lama

Bila sampel diambil saat safari katarak, maka derajat katarak penderita dengan katarak matur masuk dalam derajat 5 .

Analisa data untuk mengetahui hubungan kadar glutation reduktase (GR) pada berbagai derajat kekeruhan inti lensa pada kelompok usia yang sama dan pada derajat kekeruhan inti lensa yang sama dengan berbagai kelompok usia digunakan uji one way ANOVA dan uji korelasi Pearson menggunakan program komputer digunakan SPSS 10.01

\section{HASIL PENELITIAN}

\section{Karakteristik sampel penelitian}

Sesuai dengan kriteria inklusi didapatkan 55 penderita, berdasarkan kelompok usia didapatkan 7 penderita pada kelompok usia 40-50 tahun, 18 kelompok 50-60 tahun dan 30 kelompok usia lebih dari 60 tahun, sedang berdasarkan derajat kekeruhan inti lensa didapatkan 10 penderita termasuk derajat 2, 9 derajat 3,12 derajat 4 dan 24 derajat 5 .
Tabel 1. Distribusi Penderita

Hubungan antara Kadar enzim Glutation Reduktase dengan kelompok usia

\begin{tabular}{cccccc}
\hline USIA/DERAJAT & $\mathbf{2}$ & $\mathbf{3}$ & $\mathbf{4}$ & $\mathbf{5}$ & TOTAL \\
\hline $\mathbf{4 0 - 5 0}$ & 3 & - & 2 & 2 & 7 \\
\hline $\mathbf{5 0 - 6 0}$ & 3 & 4 & 4 & 7 & 18 \\
\hline$>60$ & 4 & 5 & 6 & 15 & 30 \\
\hline TOTAL & 10 & $\mathbf{9}$ & $\mathbf{1 2}$ & $\mathbf{2 4}$ & $\mathbf{5 5}$ \\
\hline
\end{tabular}

Tabel 2. Kadar Enzim Glutation Reduktase $(\mathrm{mU} / \mathrm{mL})$ pada masing-masing kelompok usia(tahun).

\begin{tabular}{|c|c|c|c|c|}
\hline \multirow{2}{*}{ Usia } & \multirow{2}{*}{$\Sigma$} & \multicolumn{3}{|c|}{$[\mathrm{GR}](\mathrm{mU} / \mathrm{mL})$} \\
\hline & & Min & Maks & Rata-rata $\pm S D$ \\
\hline $40-50$ & 7 & 76,41 & 213,94 & $140,23 \pm 54,04$ \\
\hline $50-60$ & 18 & 51,96 & 204,26 & $122,42 \pm 36,19$ \\
\hline \multirow[t]{2}{*}{$>60$} & 30 & 28,93 & 233,30 & $84,25 \pm 60,12$ \\
\hline & 55 & 28,93 & 233,30 & $103,87 \pm 56,37$ \\
\hline
\end{tabular}

Tabel 2 menunjukkan kadar enzim Glutation Reduktase pada masing-masing kelompok usia. Dari data di atas didapatkan kadar enzim Glutation Reduktase yang semakin rendah dengan pertambahan kelompok usia. Pada penelitian ini didapatkan berbeda nyata antar kelompok usia dengan nilai $p=0,01$. Pada perbandingan antar kelompok usia didapatkan hubungan yang signifikan antara kelompok usia 40-50 dan $>60$ dengan nilai $p=0,04$ dan antara kelompok usia 50-60 dan $>60$ dengan nilai $p=0,05$, sedangkan antara kelompok usia 40-50 dan 50-60 tidak didapatkan perbedaan yang signifikan dengan nilai $p=0,73$. Hal ini menunjukkan kadar enzim Glutation Reduktase tidak berbeda nyata antara kelompok 40-50 dan 50-60 tahun, tetapi berbeda nyata pada usia $>60$ tahun. Dari uji korekasi Pearson didapatkan $r=0.979$ 
Hubungan antara Kadar enzim Glutation Reduktase dengan derajat kekeruhan inti lensa

Tabel 3. Kadar enzim Glutation Reduktase $(\mathrm{mU} / \mathrm{mL})$ berdasar derajat kekeruhan inti lensa.

\begin{tabular}{ccccc}
\hline \multirow{2}{*}{ Derajat } & \multirow{2}{*}{$\boldsymbol{\Sigma}$} & \multicolumn{3}{c}{$[\mathrm{GR}](\mathrm{mU} / \mathrm{mL})$} \\
\cline { 3 - 5 } & & Min & Maks & Rata-rata $\pm S D$ \\
\hline 2 & 10 & 155,36 & 233,30 & $194,99 \pm 30,00$ \\
\hline 3 & 9 & 74,88 & 165,55 & $124,40 \pm 32,25$ \\
\hline 4 & 12 & 50,94 & 120,21 & $89,10 \pm 28,93$ \\
\hline 5 & 24 & 28,93 & 131,93 & $65,58 \pm 30,45$ \\
\hline Total & $\mathbf{5 5}$ & $\mathbf{2 8 , 9 3}$ & $\mathbf{2 3 3 , 3 0}$ & $\mathbf{1 0 3 , 8 7} \pm \mathbf{5 6 , 3 7}$ \\
\hline & & & & $\mathrm{P}=0,00$
\end{tabular}

Tabel 3 menggambarkan kadar enzim Glutation Reduktase pada masing-masing derajat kekeruhan inti lensa. Data ini menunjukkan kadar enzim Glutation Reduktase yang rendah terdapat pada derajat yang paling tinggi. Pada penelitian ini terdapat hubungan yang signifikan $(p=0,00)$ antar masing-masing derajat kekeruhan inti lensa.

Hasil analisa perbandingan antar derajat kekeruhan inti lensa didapatkan perbedaan yang signifikan pada derajat kekeruhan inti lensa 2 dengan $3(p=0,00), 2$ dengan $4(p=0,00), 2$ dengan $5(p=0,00), 3$ dengan $4(p=0,05)$ dan 3 dengan $5(p=0,00)$,tetapi tidak didapatkan perbedaan yang signifikan antara derajat 4 dan $5(p=0,14)$. Dari uji korelasi Pearson didapatkan $r=0,969$. Hubungan antara kadar enzim Glutation Reduktase dengan peningkatan derajat kekeruhan inti lensa pada kelompok usia yang sama.

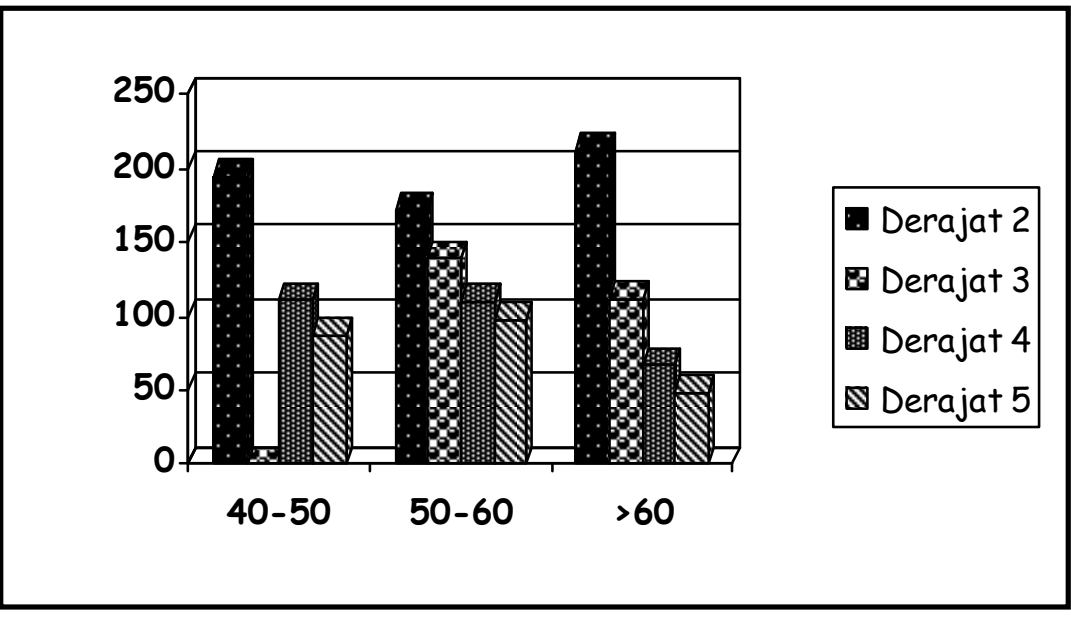

Grafik 1. Kadar GR antar derajat kekeruhan pada masing-masing kelompok usia

Kelompok usia 40-50 tahun

Tabel 4. Kadar enzim Glutation

Reduktase $(\mathrm{mU} / \mathrm{mL})$ kelompok usia 40-50 tahun pada masing-masing derajat kekeruhan inti lensa

\begin{tabular}{ccccc}
\hline \multirow{2}{*}{ Derajat } & $\boldsymbol{\Sigma}$ & \multicolumn{3}{c}{$[\mathrm{GR}](\mathrm{mU} / \mathrm{mL})$} \\
\cline { 3 - 5 } & 3 & $\mathbf{M i n}$ & Maks & Rata-rata \pm SD \\
\hline 2 & 3 & 213,94 & $195,26 \pm 17,89$ \\
4 & 2 & 102,39 & 120,21 & $111,30 \pm 12,61$ \\
5 & 2 & 76,41 & 96,78 & $86,60 \pm 14,41$ \\
\hline Total & $\mathbf{7}$ & $\mathbf{7 6 , 4 1}$ & $\mathbf{2 1 3 , 9 4}$ & $\mathbf{1 4 0 , 2 3 \pm 5 4 , 0 4}$ \\
\hline & & & $\mathrm{p}=0,00$
\end{tabular}

Tabel 4 menggambarkan kadar enzim Glutation Reduktase pada kelompok usia 40-50 tahun dibandingkan masingmasing derajatnya. Pada kelompok ini tidak didapatkan kekeruhan inti lensa derajat 3.
Didapatkan hasil rata-rata kadar enzim Glutation Reduktase yang semakin rendah dengan pertambahan derajat kekeruhan inti lensa. Pada penelitian ini didapatkan hasil yang berbeda nyata dengan $p=0,00$. 
Pada perbandingan antar derajat, didapatkan hasil berbeda nyata antara derajat 2 dan 4 dengan $p=0,01$ dan antara 2 dan 5 dengan nilai $p=0,00$ sedangkan antara derajat 4 dan 5 tidak berbeda nyata $(p=0,36)$. Dari uji korelasi

Pearson di dapatkan $r=0,994$.

Kelompok usia 50-60 tahun

Tabel 5. Kadar enzim Glutation

Reduktase (Mu/MI) kelompok usia 50-60 tahun pada masing-masing derajat kekeruhan inti lensa

\begin{tabular}{ccccc}
\hline \multirow{2}{*}{ Derajat } & $\boldsymbol{\Sigma}$ & \multicolumn{3}{c}{$[\mathrm{GR}](\mathbf{m U} / \mathrm{mL})$} \\
\cline { 3 - 5 } & 3 & Min & Maks & Rata-rata $\pm S D$ \\
\hline 2 & 155,36 & 204,26 & $171,66 \pm 28,23$ \\
3 & 4 & 124,29 & 152,82 & $139,57 \pm 14,36$ \\
4 & 4 & 104,42 & 119,20 & $110,66 \pm 6,17$ \\
5 & 7 & 51,96 & 131,93 & $98,24 \pm 33,75$ \\
\hline Total & $\mathbf{1 8}$ & $\mathbf{5 1 , 9 6}$ & $\mathbf{2 0 4 , 2 6}$ & $\mathbf{1 2 2 , 4 2 \pm 3 6 , 1 8}$ \\
\hline & & & $\mathrm{P}=0,01$
\end{tabular}

Tabel 5 menggambarkan kadar enzim Glutation Reduktase pada kelompok usia 50-60 tahun dibandingkan masingmasing derajatnya. Didapatkan hasil rata-rata kadar enzim Glutation Reduktase yang semakin rendah dengan pertambahan derajat kekeruhan inti lensa. Pada penelitian ini didapatkan hasil yang berbeda nyata dengan $p=0,01$.
Pada perbandingan antar derajat, didapatkan hasil berbeda nyata antara derajat 2 dan 4 dengan $p=0,03$ dan antara 2 dan 5 dengan nilai $p=0,01$, sedangkan antara derajat 2 dan 3 tidak berbeda nyata $(p=0,39)$, begitu pula antara 3 dan $4(p=0,41), 3$ dan 50,09$)$ serta 4 dan $5(p=0,86)$. Uji korelasi Pearson didapatkan hasil $r=0,983$.

\section{Kelompok usia $>60$ tahun}

Tabel 6. Kadar enzim Glutation Reduktase $(\mathrm{mU} / \mathrm{mL})$ kelompok usia >60tahun pada masing-masing derajat kekeruhan inti lensa

\begin{tabular}{ccccc}
\hline \multirow{2}{*}{ Derajat } & $\boldsymbol{\Sigma}$ & \multicolumn{3}{c}{$[\mathrm{GR}](\mathrm{mU} / \mathrm{mL})$} \\
\cline { 3 - 5 } & 4 & Min & Maks & Rata-rata \pm SD \\
\hline 2 & 466,06 & 233,30 & $212,29 \pm 31,82$ \\
3 & 5 & 74,88 & 165,55 & $112,27 \pm 38,88$ \\
4 & 6 & 50,94 & 117,16 & $67,32 \pm 25,47$ \\
5 & 15 & 28,93 & 63,67 & $47,54 \pm 8,67$ \\
\hline Total & $\mathbf{3 0}$ & $\mathbf{2 8 , 9 3}$ & $\mathbf{2 3 3 , 3 0}$ & $\mathbf{8 4 , 2 5 \pm 6 0 , 1 2}$ \\
\hline \multicolumn{2}{r}{} & & & $\mathrm{P}=0,00$
\end{tabular}

Tabel 6 menggambarkan kadar enzim Glutation Reduktase pada kelompok usia >60 tahun dibandingkan masingmasing derajatnya. Pada kelompok usia ini juga didapatkan hasil rata-rata kadar enzim Glutation Reduktase yang semakin rendah dengan pertambahan derajat kekeruhan inti lensa. Pada kelompok ini di dapatkan hasil yang signifikan dengan $p=0,00$. Dari hasil perbandingan antar derajat dengan hasil berbeda nyata antara derajat 2 dan $3(p=0,00), 2$ dan $4(p=0,00), 2$ dan $5(p=0,00), 3$ dan $4(p=0,02), 3$ dan $5(p=0,00)$, sedangkan antara derajat 4 dan 5 tidak berbeda nyata $(p=0,29)$. Uji korelasi Pearson di dapatkan hasil $r=0,948$ 


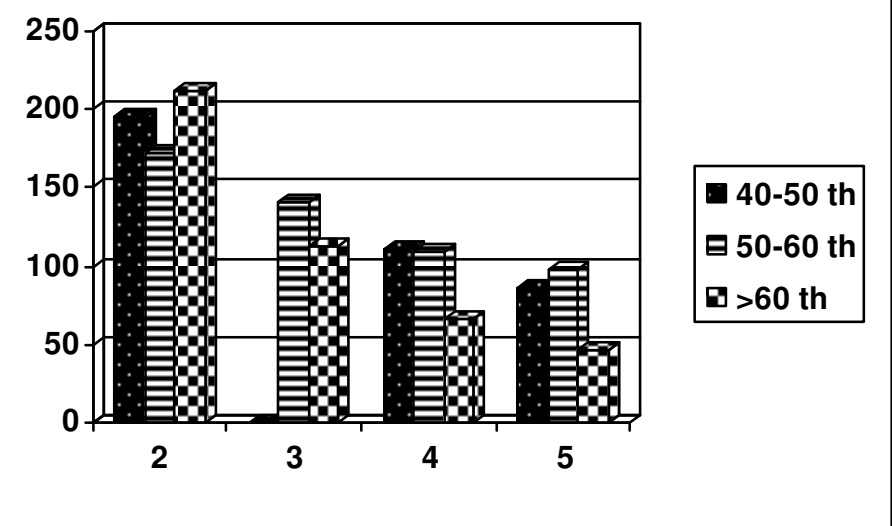

Grafik 2. Hubungan antara kadar enzim Glutation Reduktase dengan meningkatnya kelompok usia pada derajat kekeruhan inti lensa yang sama

Tabel 7. Kadar enzim Glutation Reduktase $(\mathrm{mU} / \mathrm{mL})$

kekeruhan inti lensa derajat 2 pada masing-masing kelompok usia (tahun).

\begin{tabular}{|c|c|c|c|c|}
\hline \multirow{2}{*}{ Usia } & \multirow{2}{*}{$\Sigma$} & \multicolumn{3}{|c|}{$[\mathrm{GR}](\mathrm{mU} / \mathrm{mL})$} \\
\hline & & Min & Maks & Rata-rata $\pm S D$ \\
\hline $40-50$ & 3 & 178,28 & 213,94 & $195,26 \pm 17,89$ \\
\hline $50-60$ & 3 & 155,36 & 204,26 & $171,66 \pm 28,23$ \\
\hline$>60$ & 4 & 166,06 & 233,30 & $212,29 \pm 31,82$ \\
\hline Total & 10 & 155,36 & 233,30 & $194,99 \pm 30,00$ \\
\hline
\end{tabular}

Tabel 7 menggambarkan kadar enzim Glutation Reduktase kekeruhan inti lensa derajat 2 pada masing-masing kelompok usia. Tampak hasil rata-rata kadar enzim Glutation Reduktase yang tidak semakin rendah dengan meningkatnya kelompok usia. Pada penelitian ini tidak didapatkan perbedaan yang signifikan $(p=0,22)$.

\section{Derajat kekeruhan inti lensa 3}

Tabel 8. Kadar enzim Glutation Reduktase $(\mathrm{mU} / \mathrm{mL})$

kekeruhan inti lensa derajat 3 pada masing-masing kelompok usia (tahun).

\begin{tabular}{ccccc}
\hline \multirow{2}{*}{ Usia } & \multirow{2}{*}{$\Sigma$} & \multicolumn{3}{c}{$[\mathrm{GR}](\mathrm{mU} / \mathrm{mL})$} \\
\cline { 3 - 5 } & & Min & Maks & Rata-rata $\pm S D$ \\
\hline $50-60$ & 4 & 124,29 & 152,82 & $139,57 \pm 14,36$ \\
\hline$>60$ & 5 & 74,88 & 165,55 & $112,27 \pm 38,88$ \\
\hline Total & 9 & 74,88 & 165,55 & $124,40 \pm 32,25$ \\
\hline
\end{tabular}

Pada perbandingan antar kelompok usia didapatkan signifikansi antara kelompok usia 40-50 dan 50-60 sebesar $p=0,57$, kelompok usia 40-50 dan $>60$ dengan nilai $p=0,71$ dan antara kelompok usia $50-60$ dan $>60$ dengan nilai $p=0,20$. dari uji korelasi Pearson didapatkan $r=0,413$ 
Tabel 8 menggambarkan kadar enzim Glutation Reduktase pada kekeruhan inti lensa derajat 3. Pada derajat ini tidak didapatkan sampel untuk kelompok usia 40-50 tahun. Dari hasil analisis didapatkan kadar enzim Glutation Reduktase pada kekeruhan inti lensa derajat 3 tidak berbeda nyata $(p=0,23)$

\section{Derajat kekeruhan inti lensa 4}

Tabel 9. Kadar enzim Glutation Reduktase $(\mathrm{mU} / \mathrm{mL})$ kekeruhan inti lensa derajat 4 pada masing-masing kelompok usia (tahun)

\begin{tabular}{ccccc}
\hline \multirow{2}{*}{ Usia } & \multirow{2}{*}{$\boldsymbol{\Sigma}$} & \multicolumn{3}{c}{$[\mathrm{GR}](\mathrm{mU} / \mathrm{mL})$} \\
\cline { 3 - 5 } & 2 & 102,39 & Maks & Rata-rata $\mathbf{S D}$ \\
\hline $40-50$ & 2 & 104,42 & 120,21 & $111,30 \pm 12,61$ \\
$50-60$ & 4 & 50,94 & 119,20 & $110,66 \pm 6,17$ \\
$>60$ & 6 & $\mathbf{5 0 , 9 4}$ & 117,16 & $67,32 \pm 28,47$ \\
\hline Total & $\mathbf{1 2}$ & $\mathbf{1 2 0 , 2 1}$ & $\mathbf{8 9 , 1 0 \pm 2 8 , 9 3}$ \\
\hline & & & $\mathrm{p}=0,01$
\end{tabular}

Tabel 9 menggambarkan kadar enzim Glutation Reduktase kekeruhan inti lensa derajat 4 pada masing-masing kelompok usia. Dari data diatas didapatkan kadar enzim Glutation Reduktase yang semakin rendah dengan pertambahan kelompok usia. Pada penelitian ini didapatkan hubungan yang signifikan $(p=0,01)$. Pada perbandingan antar kelompok usia didapatkan hasil signifikan antara kelompok usia 50-60 dan $>60$ dengan nilai $p=0,02$, sedangkan antara kelompok usia 40-50 dan 50-60 dengan nilai $p=1,00$ dan antara kelompok usia 40-50 dan $>60$ dengan nilai $p=0,06$ tidak didapatkan hubungan yang signifikan. Dari uji korelasi Pearson didapatkan hasil $r=0,876$.

\section{Derajat kekeruhan inti lensa 5}

Tabel 10. Kadar enzim Glutation Reduktase $(\mathrm{mU} / \mathrm{mL})$ kekeruhan inti lensa derajat 5 pada masing-masing kelompok usia.

\begin{tabular}{ccccc}
\hline \multirow{2}{*}{ Usia } & $\boldsymbol{\Sigma}$ & \multicolumn{3}{c}{$[\mathrm{GR}](\mathrm{mU} / \mathrm{mL})$} \\
\cline { 3 - 5 } & & Min & Maks & Rata-rata \pm SD \\
\hline $40-50$ & 2 & 76,41 & 96,78 & $86,60 \pm 14,41$ \\
$50-60$ & 7 & 51,96 & 131,93 & $98,24 \pm 33,75$ \\
$>60$ & 15 & 28,93 & 63,67 & $47,54 \pm 8,67$ \\
\hline Total & $\mathbf{2 4}$ & $\mathbf{2 8 , 9 3}$ & $\mathbf{1 3 1 , 9 3}$ & $\mathbf{6 5 , 5 8} \pm \mathbf{3 0 , 4 5}$ \\
\hline
\end{tabular}

Tabel 10 menggambarkan kadar enzim Glutation Reduktase kekeruhan inti lensa derajat 5 pada masingmasing kelompok usia. Dari data diatas didapatkan kadar enzim Glutation Reduktase yang semakin rendah dengan pertambahan kelompok usia. Pada penelitian ini didapatkan hubungan yang signifikan $(p=0,00)$. Pada perbedaan antar kelompok usia didapatkan perbedaan yang signifikan antara kelompok usia 40-50 dan >60 dengan nilai $p=0,04$ dan antara kelompok usia 50-60 dan $>60$ dengan nilai $p=0,00$, sedangkan antara kelompok usia 40-50 dan 50-60 tidak didapatkan perbedaan yang signifikan dengan nilai $p=0,74$. Dari uji korelasi Pearson di dapatkan hasil $r=0,731$. 



\section{DISKUSI}

Distribusi sampel pada penelitian ini kurang merata karena sampel yang diperoleh sangat bergantung pada katarak yang dilakukan ekstraksi dengan indikasi visual. Dari tabel 1 tampak pada kelompok usia 40-50 th hanya didapatkan 7 sampel sehingga estimasi jumlah sampel sebesar 13 setiap kelompok usia tidak dapat dipenuhi. Hal ini menyebabkan power penelitian pada kelompok usia tersebut menurun sampai sekitar $73,2 \%$ dari $80 \%$ yang diperkirakan $(18,19)$.

Data karakteristik pada tabel 1 tersebut juga menunjukkan semakin tua kelompok usia, jumlah penderita katarak semakin banyak dan kekeruhan inti lensa derajat tinggi juga semakin banyak. Hal ini sesuai dengan patogenesa katarak yang akan semakin berat dengan pertambahan usia. Seiring dengan pertambahan usia, berat dan ketebalan lensa meningkat dan daya akomodasi menurun. Lapisan serat yang baru terdorong secara konsentris kearah inti lensa menyebabkan penekanan dan pengerasan (nuclear sclerosis). Protein kristalin lensa berubah secara kimia dan berikatan menjadi molekul protein berat tinggi. Akibat ikatan ini meningkatkan indek refraksi lensa, penyebaran sinar yang masuk dan menurunnya kejernihan. Perubahan kimia pada protein inti lensa ini juga menyebabkan progresifitas pigmentasi. Sehingga lensa menjadi kekuningan atau kecoklatan seiring dengan bertambahnya usia $(10,11,20)$.

Pada perbedaan antara kadar enzim Glutation Reduktase dengan kelompok usia didapatkan kadar yang semakin rendah dengan pertambahan usia (tabel 2), tetapi pada perbandingan antar kelompok usia hanya didapatkan perbedaan yang signifikan antara kelompok usia 40-50 dan $>60$ dengan nilai $p=0,04$ dan antara kelompok usia $50-60$ dan $>60$ dengan nilai $p=0,05$, sedangkan antara kelompok usia 40-50 dan 50-60 tidak didapatkan perbedaan yang signifikan dengan nilai $p=0,73$ (Tabel 3). Hal ini menunjukkan kadar enzim Glutation Reduktase tidak berbeda nyata antara kelompok 40-50 dan 50-60 tahun, tetapi berbeda nyata pada usia $>60$ tahun. Hal ini kemungkinan berkaitan dengan konsentrasi GSH-3OHKG dan 3OHKG yang berikatan dengan protein mulai meningkat secara cepat setelah dekade ke-5 kehidupan dimana terjadi keadaan biokimia yang memacu proses deaminasi $(9,13,17)$.

Pada perbedaan antara kadar enzim Glutation Reduktase dengan derajat kekeruhan inti lensa didapatkan kadar yang semakin rendah dengan pertambahan derajat kekeruhan inti (tabel 4). Pada perbandingan antar derajat kekeruhannya didapatkan hubungan yang signifikan antar semua derajat kekeruhan inti lensa, kecuali antara derajat kekeruhan 4 dan 5 (Tabel 5). Hasil yang sama juga didapatkan pada perbandingan antar derajat kekeruhan inti pada kelompok usia 40-50 dan >60 tahun. Belum dapat dijelaskan apakah hal ini menunjukkan kandungan biokimiawi antara derajat kekeruhan 4 dan 5 tidak jauh berbeda. Diperlukan penelitian lebih lanjut untuk memperjelas hal tersebut. Hal ini dapat juga dipengaruhi oleh subyektifitas pada cara pengelompokan derajat kekeruhan inti lensa karena pada derajat 4 dan 5 kekeruhan telah mengenai hampir seluruh inti lensa dan dapat pula disertai kekeruhan kortek sehingga semakin sulit pengelompokan pada kedua derajat ini.

Dari hasil analisis data hubungan antara kadar enzim Glutation Reduktase pada kelompok usia yang sama terhadap derajat kekeruhan inti lensa didapatkan signifikan pada semua kelompok usia, hal ini menunjukkan bahwa kadar enzim Glutation Reduktase semakin rendah dengan pertambahan derajat kekeruhan inti lensa pada kelompok usia yang sama (Tabel 6,8,10). Tetapi perbandingan kadar enzim Glutation Reduktase antar derajat kekeruhannya dalam kelompok usia yang sama didapatkan tidak selalu berbeda nyata $(7,9,11)$, hal ini menunjukkan rata-rata kadar enzim Glutation Reduktase pada satu derajat tidak dapat dijadikan patokan bahwa kadar tersebut menunjukkan derajat tertentu. Dari hasil analisa hubungan antara kadar enzim Glutation Reduktase pada kelompok usia yang sama terhadap derajat kekeruhan inti lensa (Tabel 6,8,10) dapat diinterpretasikan bahwa rendahnya kadar enzim Glutation Reduktase lebih berpengaruh pada peningkatan derajat kekeruhan inti lensa dibandingkan peningkatan kelompok usia. Hal ini tidak sesuai dengan penelitian sebelumnya yang menyebutkan penurunan kadar GSH sesuai dengan peningkatan usia (13). Tetapi belum didapatkan data penelitian sebelumnya yang menyebutkan adanya hubungan antara kadar GSH dengan derajat kekeruhan inti lensa.

Perbedaan antara kadar enzim Glutation Reduktase pada derajat kekeruhan inti lensa terhadap kelompok usia yang berbeda didapatkan bahwa antar masing-masing kelompok usia kadar enzim Glutation Reduktase pada derajat 2 tidak berbeda nyata (Tabel 12). Hal ini kemungkinan karena katarak dengan kekeruhan inti lensa derajat 2 secara klinis dapat juga disertai dengan kekeruhan bagian lensa yang lain misalnya katarak subkapsular atau kortikal. Masih diperlukan penelitian lebih lanjut apakah katarak subkapsular atau kortikal juga dipengaruhi rendahnya kadar enzim Glutation Reduktase. Kesulitan untuk mempelajari hal ini mungkin terhambat oleh teknik operasi ekstra kapsular, sehingga yang dapat diekstraksi adalah bagian inti lensa $(21,22)$.

Perbedaan antara kadar enzim Glutation Reduktase pada derajat kekeruhan inti lensa yang sama terhadap kelompok usia yang berbeda didapatkan hasil pada derajat rendah (2 dan 3) dan kelompok usia muda (40-50 tahun) kadar enzim Glutation Reduktase tidak berbeda nyata. Hal ini menggambarkan terjadinya kekeruhan inti lensa tidak 
hanya dipengaruhi oleh rendahnya kadar enzim Glutation Reduktase, tetapi kemungkinan juga dipengaruhi oleh faktor yang lain yang berperan pada terjadinya katarak misal genetik, gizi, merokok dan paparan sinar ultraviolet $(9,10,23)$

Hubungan yang tidak signifikan pada usia yang muda ( kelompok usia 40-50 dan 50-60) dapat pula menunjukkan bahwa pengaruh enzim Glutation Reduktase kemungkinan lebih berpengaruh pada kelompok usia lebih dari 60 tahun. Hal ini sesuai dengan Bova et al yang menyebutkan penurunan kadar GSH dan peningkatan kadar GSSG sesuai dengan peningkatan usia (13). Tetapi adanya angka-angka yang tidak signifikan kemungkinan menunjukkan masih adanya faktor lain yang berpengaruh dalam proses biokimiawi ini.

Kendala pada penelitian ini adalah cara pengelompokan derajat katarak yang masih lebih bersifat subyektif karena keterbatasan alat pemeriksaan. Kendala lain adalah sampel yang sulit dicari karena sampel yang didapat tergantung pada operasi katarak atas indikasi visual, sedang penderita katarak pada usia muda sangat sedikit jumlahnya dan katarak dengan kekeruhan inti yang tipis tidak mungkin dilakukan operasi ekstraksi kecuali disertai kekeruhan bagian lain seperti subkapsular atau kortek. Disamping hal diatas, penelitian ini juga dibatasi oleh waktu.

\section{KESIMPULAN}

Berdasarkan penelitian yang telah dilakukan dapat diambil kesimpulan bahwa pada katarak senilis rendahnya kadar enzim glutation reduktase berhubungan dengan meningkatnya kelompok usia dan derajat kekeruhan inti lensa. Tetapi tidak pada katarak senilis dengan kelompok usia yang sama.

Meningkatnya derajat kekeruhan inti lensa juga berhubungan dengan rendahnya kadar Enzim Glutation reduktase, tetapi pada derajat kekeruhan inti lensa yang sama, meningkatnya kelompok usia tidak selalu berhubungan dengan rendahnya kadar enzim glutation reduktase.

Hubungan antara usia dan derajat kekeruhan inti lensa dengan kadar Enzim Glutation Reduktor menunjukkan hubungan yang kuat $(r>0,9)$ semakin lanjut usia dan semakin keruh lensa kadar Enzim Glutation Reduktase akan semakin turun. Sedangkan hubungan antara derajat kekeruhan inti lensa yang sama dengan meningkatnya kelompok usia tidak begitu kuat. $(r<0,5)$

\section{SARAN}

Diharapkan hasil penelitian ini dapat menjadi dasar lebih lanjut untuk dilakukan penelitian berikutnya yang akan semakin memperjelas peranan enzim glutation reduktase dalam mekanisme timbulnya katarak.

\section{DAFTAR KEPUSTAKAAN}

1. Fu S, Dean R, Southan M, Truscott R. The Hydroxyl Radical in Lens Nuclear Cataractogenesis. The Journal of Biological Chemistry, 1998,.273, 44, 28603-9.

2. Leske M C, Chylack LT, He Q, et al. Antioxidant Vitamins and Nuclear Opacities- The Longitudinal Study of Cataract. Ophthalmology 1998; 105: 831-836.

3. Sperduto. Epidemiologic Aspects of Age-Related Cataract. In: William Tasman, Edward A. Jaeger. Duane's Clinical Ophthalmology. Volume 1. Philadelphia: J.B. Lippincott Company, 1994; 73 A: 1-2.

4. Gondhowiardjo TD. Aktifitas Enzim Aldehid Dehidrogenase pada Lensa Katarak Diabetes dan Non-Diabetes. Ophthalmologica Indonesiana 1996; 16(2): 118-24.

5. Apple et al. Survey of Ophthalmology. 45(1 ) 2000. S13-S21.

6. Forrester J V. Aging and Vision. Br J Ophthalmol 1997; 81: 809-10.

7. Refa Safaruddin. Pelayanan Katarak Terpadu. Bagian Ilmu Penyakit Mata FK Unibraw/ RSSA Malang, 2001: 1-2.

8. Suhendro G. Pembentukan Sikatrik Retina Perifer Pada Nonproliferatif Retinopati Diabetik Untuk Mempertahankan Sistem Autoregulasi Retina Sentral (dissertation). Surabaya; Universitas Airlangga; 1999.

9. Hood BD, Garner B, Truscott RJW. Human Lens Coloration and Aging: Evidence for Crystallin Modification by The Major Ultraviolet Filter, 3-Hydroxy-Kynurenine O-D-Glucoside. J Biol Chem. 1999. 274(46): 32547-50.

10. American Academy of Ophthalmology staff. International Ophthalmology. In: Basic and Clinical Science Course. Section 13. San Francisco: The Foundation of the American Academy of Ophthalmology, 2003: 157-66.

11. Delamere NA, Paterson CA. The Crystalline Lens. In: William Tasman, Edward A. Jaeger. Duane's Clinical Ophthalmology 2. Philadelphia: J.B. Lippincott Company, 1994; 10: 1-19.

12. Linetsky M, Chemoganskiy V G, Hu Fang, Ortmerth BJ. Effect of UV A Light on the Activity of Several Aged Human Lens Enzymes. Invest. Ophthalm. And Vis Scie. 2003; 44: 264-74. 
13. Bova LM, Sweeney MHJ, Jamie JF, Truscott RJW. Major Changes in Human Ocular UV Protection with Age. Invest. Ophthalm. And Vis Scie. 2001;42:200-5.

14. Vasquez S, Nicole R P, Sheil M, Truscott JW. Protein-Bound Kynurenine Decreases with the Progression of AgeRelated Nuclear Cataract. Invest Ophthalmol Vis Sci. 2004; 45: 879-83.

15. Bova LM, Wood AM, Jamie JF, Truscott RJW. UV Filter Compounds in Human Lenses: the Origin of 4-(2-Amino-3, hydroxyphenyl)-4-oxobutanoic Acid O- $\beta$-D- Glucoside. Invest. Ophthalm. And Vis Scie. 1999;40:3237-44.

27. Kidd PM. Glutathione: Systemic Protectant Against Oxidative and Free Radical Damage. Alt Med Rev.1997; 2(3): 155-76.

28. Mayes PA. Metabolisme Karbohidrat. In: David W Martin, Jr. Alih Bahasa: Iyan Darmawan. Biokimia. Ed 20, Jakarta: EGC, 1987; 15: 202-4.

29. Fred MW. Practical Ophthalmology: Amanual for Beginning Residents. San Francisco: American Academy of Ophthalmology, 1996; 10: 220-1.

30. Kuzma JW, Bohnenblust. Basic Statistics for the Health Sciences. $5^{\text {th }}$ Ed. Boston: Mc Graw- Hill, 2005; 7: 106-122.

31. American Academy of Ophthalmology staff. Lens and Cataract. In: Basic and Clinical Science Course. Section 11. San Francisco: The Foundation of the American Academy of Ophthalmology, 2003: 5-49.

32. Buratto L. Cataract Surgery Development and techniques. In: Lucio Buratto. Phacoemulsification: Principles and techniques. Thorofore: SLACK, Inc,1998; 1:5-7.

33. Budiman. Transisi dari Ekstraksi Katarak Ekstrakapsular ke Fakoemulsifikasi. In: Kumpulan naskah Seminar Bedah Katarak Incisi kecil dan Fakoemulsifikasi. Semarang: Perdami cabang Jawa Tengah., 2001.

34. Datiles MB, Kinoshita JH. Pathogenesis of Cataracts. In: William Tasman, Edward A. Jaeger. Duane's Clinical Ophthalmology. Volume 1. Philadelphia: J.B. Lippincott Company, 1994; 72 B: 1-14. 
16. Kidd PM. Gkutathione: Systemic Protectant Againts Oxidative and Free Radical Damage. Alt Med Rev.1997; 2(3): 155-7 EGC, 1987; 15: 202- 4.y Ophthalmologi, 1996; 10: 220-1.

17. Mayes PA. Metabolisme Karbohidrat. In: David W Martin, Jr. Alih Bahasa: Iyan Darmawan. Biokimia. Ed 20, Jakarta: EGC, 1987; 15: 202-4.

18. Fred MW. Practical Ophthalmology: Amanual for Beginning Residents. San Francisco: American Academy of Ophthalmology, 1996; 10: 220-1.

19. Kuzma JW, Bohnenblust. Basic Statistics for the Health Sciences. $5^{\text {th }}$ Ed. Boston: Mc Graw- Hill, 2005; 7: 106122.

20. American Academy of Ophthalmology staff. Lens and Cataract. In: Basic and Clinical Science Course. Section 11. San Francisco: The Foundation of the American Academy of Ophthalmology, 2003: 5-49.

21. Buratto L. Cataract Surgery Development and techniques. In: Lucio Buratto. Phacoemulsification: Principles and techniques. Thorofore: SLACK, Inc,1998; 1:5-7.

22. Budiman. Transisi dari Ekstraksi Katarak Ekstrakapsular ke Fakoemulsifikasi. In: Kumpulan naskah Seminar Bedah Katarak Incisi kecil dan Fakoemulsifikasi. Semarang: Perdami cabang Jawa Tengah., 2001.

23. Datiles MB, Kinoshita JH. Pathogenesis of Cataracts. In: William Tasman, Edward A. Jaeger. Duane's Clinical Ophthalmology. Volume 1. Philadelphia: J.B. Lippincott Company, 1994; 72 B: 1-14.

\section{DAFTAR KEPUSTAKAAN}

35. Fu S, Dean R, Southan M, Truscott R. The Hydroxyl Radical in Lens Nuclear Cataractogenesis. The Journal of Biological Chemistry, 1998,.273, 44, 28603-9.

36. Leske M C, Chylack LT, He Q, et al. Antioxidant Vitamins and Nuclear Opacities- The Longitudinal Study of Cataract. Ophthalmology 1998; 105: 831-836.

37. Sperduto. Epidemiologic Aspects of Age-Related Cataract. In: William Tasman, Edward A. Jaeger. Duane's Clinical Ophthalmology. Volume 1. Philadelphia: J.B. Lippincott Company, 1994; 73 A: 1-2.

38. Gondhowiardjo TD. Aktifitas Enzim Aldehid Dehidrogenase pada Lensa Katarak Diabetes dan Non-Diabetes. Ophthalmologica Indonesiana 1996; 16(2): 118-24.

39. Apple et al. Survey of Ophthalmology. 45(1) 2000. S13-S21.

40. Forrester J V. Aging and Vision. Br J Ophthalmol 1997; 81: 809-10.

41. Refa Safaruddin. Pelayanan Katarak Terpadu. Bagian IImu Penyakit Mata FK Unibraw/ RSSA Malang, 2001: 1-2.

42. Suhendro G. Pembentukan Sikatrik Retina Perifer Pada Nonproliferatif Retinopati Diabetik Untuk Mempertahankan Sistem Autoregulasi Retina Sentral (dissertation). Surabaya; Universitas Airlangga; 1999.

43. Hood BD, Garner B, Truscott RJW. Human Lens Coloration and Aging: Evidence for Crystallin Modification by The Major Ultraviolet Filter, 3-Hydroxy-Kynurenine O-D-Glucoside. J Biol Chem. 1999. 274(46): 32547-50.

44. American Academy of Ophthalmology staff. International Ophthalmology. In: Basic and Clinical Science Course. Section 13. San Francisco: The Foundation of the American Academy of Ophthalmology, 2003: 157-66.

45. Delamere NA, Paterson CA. The Crystalline Lens. In: William Tasman, Edward A. Jaeger. Duane's Clinical Ophthalmology 2. Philadelphia: J.B. Lippincott Company, 1994; 10: 1-19.

46. Linetsky M, Chemoganskiy V G, Hu Fang, Ortmerth BJ. Effect of UV A Light on the Activity of Several Aged Human Lens Enzymes. Invest. Ophthalm. And Vis Scie. 2003; 44: 264-74.

47. Bova LM, Sweeney MHJ, Jamie JF, Truscott RJW. Major Changes in Human Ocular UV Protection with Age. Invest. Ophthalm. And Vis Scie. 2001;42:200-5.

48. Vasquez S, Nicole R P, Sheil M, Truscott JW. Protein-Bound Kynurenine Decreases with the Progression of AgeRelated Nuclear Cataract. Invest Ophthalmol Vis Sci. 2004; 45: 879-83.

15. Bova LM, Wood AM, Jamie JF, Truscott RJW. UV Filter Compounds in Human Lenses: the Origin of 4-(2-Amino-3, hydroxyphenyl)-4-oxobutanoic Acid O-B-D- Glucoside. Invest. Ophthalm. And Vis Scie. 1999;40:3237-44. 


\section{HUBUNGAN ANTARA KADAR ENZIM GLUTATION REDUKTASE DENGAN DERAJAT KEKERUHAN INTI LENSA \\ dr.T Budi Sulistya,SpM, dr.Debby Shintiya Dewi,SpM, dr.Hidayat Suyuti,PhD, Prof.DR.dr.Sumarno,SpMK}

\section{ABSTRACT}

The aim of this study was To determine the correlation between the level of glutathione reductase [GR] in relation with the severity of nuclear cataract and the increase of age.

An analytic cross sectional observasional study of nuclear cataract patient seen at Saiful Anwar Hospital and Mass Cataract Surgery performed by Perdami Malang. Patient were classified into 3 groups base on age and 4 groups base on severity of nuclear cataract. The sample were taken by consecutive sampling and were operated on visual indication. The extracted lens were examined for [GR]. The laboratory findings of [GR] were compared with the severity of senile cataract. The data were analyses with one way ANOVA. Confidence limit was set at 95\%.

A total of 55 patient were included with the sample size in 40-50 age group less than estimation. [GR] were found to be significanfly lower in the older age $(p=0,01)$ and the more severe cataract groups $(p=0,00)$. The [GR] were also found to be significantly lower with increase of cataract severity in 40-50 age group $(p=0,00), 50-60$ age group $(p=0,01)$ and $>60$ age group $(p=0,00)$.

The conclusion was the increase of age and severity of nuclear cataract In senile cataract, were associated with the low [GR]. This association were also found, with the increase of cataract severity in the same age group. However, in the same cataract grade the increase of age is not always associated with a low [GR].

Im the grade 2 cataract, there were no significant difference of [GR] between age group ( $p=0.22$ ). This also occur in grade $3(p=0.23)$ while in the grade 4 , there wee 2 significant difference between age group $(p=0.01)$. This also occur in grade $5(p=0.06)$. Pearson correlation test showed that there was strong correlation between [GR] and increase of age $(r=0.979)$ and cataract severity $(r=0.969)$, but in the rame cataract grade, the increase of age is not always associated with 2 low [GR] ( $r=0.413$,for grade 2, $r=0.876$ for grade 4 and $r=0.731$ for grade 5 ). 
Key words $\quad$ : senile cataract - glutathione reductase - nuclear cataract grade - age 


\section{PENDAHULUAN}

Katarak senilis (Age-related Cataract) merupakan salah satu problem utama kesehatan masyarakat di dunia.1,2 Di negara sedang berkembang, dimana fasilitas kesehatan masih terbatas, terutama fasilitas operasi, buta katarak mencapai hampir setengah dari semua kebutaan. ${ }^{1,3-5}$ Angka kebutaan didunia 0,1-0,4\% pada negara maju, sedang di negara sedang berkembang tercatat 0,5-1,5\% dengan sebab utama katarak., ${ }^{4,6}$ Di Indonesia menurut Survei Kesehatan Indra Penglihatan dan Pendengaran Tahun 1993-1996 angka kebutaan $1,5 \%$ dengan penyebab utama katarak $(0,78 \%), 7,8$

Faktor resiko terjadinya katarak senilis sangat beragam. Faktor personal seperti usia, jenis kelamin, etnis dan keturunan sangat penting. Saat ini penelitian dilakukan pada interaksi antara genetik dan lingkungan yang mempengaruhi genetik tersebut. Faktor lingkungan sangat penting dalam kataraktogenesis. Faktor-faktor tersebut sering terjadi pada masyarakat misal merokok dan paparan sinar ultraviolet. Merokok dapat meningkatkan kejadian katarak inti dan sub kapsular posterior ( PSC ), sedang katarak kortikal dan inti berhubungan dengan paparan lama sinar ultraviolet. 9,10

Katarak adalah keadaan dimana lensa menjadi keruh atau kehilangan transparansinya. Supaya mata dapat berfungsi dengan baik memerlukan lensa yang bening / transparan dan lentur / elastis. Lensa berfungsi sebagai media refraksi, yang berperan secara pasif dalam proses akomodasi sehingga sinar yang melalui kornea dan humor akuos dapat difokuskan di retina dan menghasilkan tajam penglihatan yang baik. Transparansi lensa ini dipertahankan oleh keseragaman serat, keseragaman distribusi dan komposisi protein kristalin dalam lensa. ${ }^{11-4}$

Dengan pertambahan usia, sifat tranparansi lensa ini dapat menurun oleh karena lensa mengalami perubahan ikatan struktur protein dan penguningan inti, sehingga terjadi peningkatan kekeruhan inti lensa. Akhir-akhir ini telah diketahui tentang adanya penyaring ultraviolet yang berperan penting dalam terjadinya pewarnaan lensa manusia normal dan pembentukan katarak. Struktur tersebut adalah L-3-Hydroxykynurenine O-ß-D- glucoside (3OHKG) yang berikatan dengan kristalin. Ikatan tersebut menghasikan komponen yang secara karakteristik ditemukan pada lensa katarak senilis. ${ }^{11,15-8}$

Dalam kaitan dengan proses penyaring ultraviolet (UV filter) ini, terkait pula peran glutation teroksidasi dan tereduksi. Glutation tereduksi(GSH) akan mengikat penyaring ultraviolet (3OHKG) yang terdeaminasi supaya tidak berikatan dengan protein kristalin sehingga tidak terjadi pewarnaan dan kekeruhan lensa. Kadar Glutation tereduksi(GSH) ini mulai usia 40 tahun semakin menurun dengan pertambahan usia dan hal ini semakin meningkatkan ikatan 3OHKG dengan kristalin. Ikatan 3OHKG dengan kristalin ini tidak didifusikan keluar lensa sehingga akan semakin menumpuk dalam lensa, terutama inti, menyebabkan terjadinya halangan difusi antara kortek dan inti yang pada proses selanjutnya akan semakin mengurangi kadar Glutation tereduksi(GSH). Ketersediaan Glutation tereduksi(GSH) sendiri harus melalui proses reaksi yang dikatalisasi oleh enzim Glutation reduktase(GR) yang merubah glutation teroksidasi (GSSG) menjadi Glutation tereduksi (GSH). ${ }^{11,16,19,20}$

Akhir-akhir ini dikemukakan bahwa konsentrasi Glutation teroksidasi (GSSG) pada inti lensa mulai usia 20 tahun meningkat secara nyata dengan pertambahan usia, tetapi kadar Glutation tereduksi (GSH) menurun sangat rendah. Padahal pada kondisi normal GSSG dapat dirubah menjadi GSH dengan proses katalisasi oleh enzim Glutation reduktase(GR). Ketersediaan GSH yang mencukupi akan mencegah ikatan penyaring ultraviolet 3OHKG dengan protein kristalin yang dapat menyebabkan kekeruhan inti lensa. Konsentrasi GSH inti lensa yang rendah menyebabkan penyaring ultraviolet berikatan dengan kristalin, sehingga terjadi pewarnaan dan rusaknya struktur kristalin. Kerusahan hebat pada kristalin juga terjadi bila kadar GSH turun hingga $1 \mathrm{mM}$, menyebabkan awal terjadinya katarak inti. ). $., 11,15,17,20,21$

Menurut Bova et al (2001) Konsentrasi Glutation teroksidasi (GSSG ) pada inti lensa meningkat secara nyata dengan pertambahan usia. Konsentrasi terendah didapatkan pada usia kurang dari 20 tahun yaitu antara $0.1-0,3 \mathrm{mM}$, sedang pada decade ke-8 kehidupan menjadi 0,5-0,6mM. Sedangkan kadar GSH inti 4,5mM pada usia 20 tahun dan menurun 7\% perdekade menjadi $3 \mathrm{mM}$ pada dekade ke $9 .{ }^{16}$

Secara teori anti oksidan dapat melindungi protein dan membrane dari paparan oksidatif yang mencegah kataraktogenesis. Berbagai diet dan suplemen dengan berbagai efek antioksidan telah diteliti, tetapi hasilnya belum memuaskan. ${ }^{10}$

Berdasarkan fakta-fakta diatas, penelitian ini dikerjakan untuk mengetahui apakah pada katarak senilis meningkatnya kelompok usia berhubungan dengan rendahnya kadar enzim glutation reduktase dan apakah pada katarak senilis meningkatnya derajat kekeruhan inti lensa berhubungan dengan rendahnya kadar enzim glutation reduktase. Selain hal tersebut diatas, penulis juga ingin mengetahui apakah pada katarak senilis dengan kelompok usia yang sama, meningkatnya derajat kekeruhan inti lensa berhubungan dengan rendahnya kadar enzim glutation reduktase dan apakah pada katarak senilis dengan derajat kekeruhan inti lensa yang sama, meningkatnya kelompok usia berhubungan dengan rendahnya kadar enzim glutation reduktase. Selanjutnya diharapkan dengan penelitian ini dapat diketahui enzim yang berperan dalam mekanisme timbulnya katarak dan dapat mencegah atau memperlambat terjadinya katarak senilis, memperkaya kasanah ilmu pengetahuan dan menjadi dasar penelitian selanjutnya yang berkaitan.

\section{BAHAN DAN CARA}

Penelitian ini merupakan penelitian analitik cross sectional yang dilakukan di RS dr. Saiful Anwar Malang, safari katarak di Puskesmas binaan Perdami cabang Malang dan Laboratorium Biomedik FK Unibraw. Penelitian dilakukan pada Agustus 2004 sampai dengan Februari 2006. Sampel penelitian diambil secara consecutive sampling dari penderita operasi ekstraksi katarak atas indikasi visual di Bagian Mata RSSA Malang dan safari katarak di Puskesmas binaan Perdami cabang Malang.

Buratto. ${ }^{8}$

Pemeriksaan derajat kekeruhan inti lensa dengan alat biomikroskop Slit-lamp ${ }^{22}$ dinilai pewarnaan pada inti sesuai klasifikasi 
Pemeriksaan Glutation reduktase bahan penelitian inti lensa dengan cara sampel disimpan dalam tempat tertutup steril dan disimpan dalam keadaan membeku pada suhu $-20^{\circ} \mathrm{C}$. Sampel dikelompokan sesuai kelompok usia dan derajat kekeruhan kataraknya

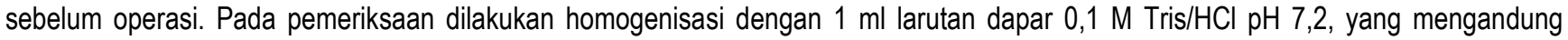
$154 \mathrm{mM} \mathrm{NaCl}$ dalam suhu $4^{\circ} \mathrm{C}$. Selanjutnya dilakukan pemusingan dengan $3.000 \times \mathrm{g}$ selama 20 menit dalam $4^{\circ} \mathrm{C}$, bagian larutan ( supernatant) nya dipisahkan untuk langsung dianalisa atau kembali dibekukan pada $-20^{\circ} \mathrm{C}$.

Kadar glutation reduktase diukur menurut prosedur Carlberg dan Mannervik. Sebanyak $50 \mu \mathrm{L}$ hasil larutan homogenate lensa ditambahkan kedalam 1,55mL campuran larutan yang terdiri dari $100 \mathrm{mM}$ buffer $\mathrm{KPO}_{4}(\mathrm{pH} 8,0), 1,0 \mathrm{mM}$ EDTA, 1,0 mM glutation teroksidasi (GSSG) dan 0,2 mM NADPH. dan penurunan densitas optical dari larutan ini dicatat dengan menggunakan spektrofotometer ( Spektrofotometer fluorescen merk Simatsu 2000 ) pada panjang gelombang $340 \mathrm{~nm}$ yang direkam pada suhu $25^{\circ} \mathrm{C}$. Satu unit enzim didefinisikan sebagai $1 \mu \mathrm{mol} / \mathrm{min} \mathrm{NADPH}$ teroksidasi pada $25^{\circ} \mathrm{C} .5,15$

Kriteria Inklusi pada penelitian ini penderita laki-laki dan wanita, berusia lebih dari 40 tahun, penderita dengan kekeruhan inti lensa berbagai derajat, setuju dan menandatangani Informed consent dilakukan operasi katarak ekstraksi atas indikasi visual.

Kriteria Eksklusi adalah bila ekstrak sampel lensa yang didapat setelah proses tidak memenuhi kriteria, katarak komplikata, katarak dengan komplikasi, disertai Diabetes mellitus atau setelah regulasi Diabetes mellitus.

Definisi Operasional Katarak adalah kekeruhan lensa dengan derajat kekeruhan menurut Buratto 8

Derajat 1:inti transparan atau abu muda, umumnya kekeruhan pada kortek atau subkapsular, seperti pada katarak presenilis.

Derajat 2:katarak inti abu muda atau kuning-abu. Terdapat pada katarak presenilis, terutama katarak subkapsular posterior.

Derajat 3:khas pada katarak senilis. Berwarna kuning jika katarak inti predominan pada bagian perifer lensa. Dapat berwarna abu pada katarak dengan komponen kortiko-kapsular pada pasien > 60-65 tahun.

Derajat 4:berwarna kuning-coklat dan terdapatpada katarak senilis lanjut dengan bagian inti besar.

Derajat 5:inti berwarna coklat-hitam. Merupakan katarak senilis yang sudah sangat lama

Bila sample diambil saat safari katarak, maka derajat katarak penderita dengan katarak matur masuk dalam derajat 5 .

Analisa data untuk mengetahui hubungan kadar glutation reduktase (GR) pada berbagai derajat kekeruhan inti lensa pada kelompok usia yang sama dan pada derajat kekeruhan inti lensa yang sama dengan berbagai kelompok usia digunakan uji one way ANOVA

Analisa program komputer digunakan SPSS 10.01

\section{HASIL}

\section{Karakteristik sampel penelitian}

Sesuai dengan kriteria inklusi didapatkan 55 penderita, berdasarkan kelompok usia didapatkan 7 penderita pada kelompok usia 40-50 tahun, 18 kelompok 50-60 tahun dan 30 kelompok usia lebih dari 60 tahun, sedang berdasarkan derajat kekeruhan inti lensa didapatkan 10 penderita termasuk derajat 2, 9 derajat 3,12 derajat 4 dan 24 derajat 5.

Tabel 1. Distribusi Penderita

\section{Hubungan antara Kadar enzim Glutation Reduktase dengan} kelompok usia

\begin{tabular}{|c|c|c|c|c|c|}
\hline USIA/DERAJAT & $\mathbf{2}$ & $\mathbf{3}$ & $\mathbf{4}$ & $\mathbf{5}$ & TOTAL \\
\hline $\mathbf{4 0 - 5 0}$ & 3 & - & 2 & 2 & 7 \\
\hline $\mathbf{5 0 - 6 0}$ & 3 & 4 & 4 & 7 & 18 \\
\hline$>60$ & 4 & 5 & 6 & 15 & 30 \\
\hline TOTAL & $\mathbf{1 0}$ & $\mathbf{9}$ & $\mathbf{1 2}$ & $\mathbf{2 4}$ & $\mathbf{5 5}$ \\
\hline
\end{tabular}

Tabel 2. Kadar enzim Glutation Reduktase(mU/mL) pada masing-masing kelompok usia(tahun).

\begin{tabular}{ccccc}
\hline \multirow{2}{*}{ Usia } & \multirow{\Sigma}{*}{$\boldsymbol{\Sigma}$} & \multicolumn{3}{c}{$[\mathrm{GR}](\mathrm{mU} / \mathrm{mL})$} \\
\cline { 3 - 5 } & & Min & Maks & Rata-rata \pm SD \\
\hline $40-50$ & 7 & 76,41 & 213,94 & $140,23 \pm 54,04$ \\
$50-60$ & 18 & 51,96 & 204,26 & $122,42 \pm 36,19$ \\
$>60$ & 30 & 28,93 & 233,30 & $84,25 \pm 60,12$ \\
\hline & $\mathbf{5 5}$ & $\mathbf{2 8 , 9 3}$ & $\mathbf{2 3 3 , 3 0}$ & $\mathbf{1 0 3 , 8 7 \pm 5 6 , 3 7}$ \\
\hline & & & & $\mathrm{p}=0,01$
\end{tabular}

Tabel 2 menunjukkan kadar enzim Glutation Reduktase pada masing-masing kelompok usia. Dari data diatas didapatkan kadar enzim Glutation Reduktase yang semakin rendah dengan pertambahan kelompok usia. Pada penelitian ini didapatkan berbeda nyata antar kelompok usia dengan nilai $p=0,01$. Pada perbandingan antar kelompok usia didapatkan hubungan yang signifikan antara kelompok usia 40-50 dan >60 dengan nilai $p=0,04$ dan antara kelompok usia 50-60 dan $>60$ dengan nilai $p=0,05$, sedangkan antara 
kelompok usia 40-50 dan 50-60 tidak didapatkan hubungan yang signifikan dengan nilai $p=0,73$. Hal ini menunjukkan kadar enzim Glutation Reduktase tidak berbeda nyata antara kelompok 40-50 dan 50-60 tahun, tetapi berbeda nyata pada usia >60 tahun.

\section{Hubungan antara Kadar enzim Glutation Reduktase dengan derajat kekeruhan inti lensa}

Tabel 3. Kadar enzim Glutation Reduktase $(\mathrm{mU} / \mathrm{mL})$ berdasar derajat kekeruhan inti lensa.

\begin{tabular}{ccccc}
\hline \multirow{2}{*}{ Derajat } & \multirow{\Sigma}{}{$\boldsymbol{\Sigma}$} & \multicolumn{3}{c}{$[\mathrm{GR}](\mathrm{mU} / \mathrm{mL})$} \\
\cline { 3 - 5 } & & Min & Maks & Rata-rata \pm SD \\
\hline 2 & 10 & 155,36 & 233,30 & $194,99 \pm 30,00$ \\
3 & 9 & 74,88 & 165,55 & $124,40 \pm 32,25$ \\
4 & 12 & 50,94 & 120,21 & $89,10 \pm 28,93$ \\
5 & 24 & 28,93 & 131,93 & $65,58 \pm 30,45$ \\
\hline Total & $\mathbf{5 5}$ & $\mathbf{2 8 , 9 3}$ & $\mathbf{2 3 3 , 3 0}$ & $\mathbf{1 0 3 , 8 7} \pm \mathbf{5 6 , 3 7}$ \\
\hline & & & & $\mathrm{P}=0,00$
\end{tabular}

Tabel 3 menggambarkan kadar enzim Glutation Reduktase pada masing-masing derajat kekeruhan inti lensa. Data ini menunjukkan kadar enzim Glutation Reduktase yang rendah terdapat pada derajat yang paling tinggi. Pada penelitian ini terdapat hubungan yang signifikan $(\mathrm{p}=0,00)$ antar masing-masing derajat kekeruhan inti lensa.

Hasil analisa perbandingan antar derajat kekeruhan inti lensa didapatkan hubungan yang signifikan pada derajat kekeruhan inti lensa 2 dengan $3(p=0,00), 2$ dengan $4(p=0,00)$, 2 dengan $5(p=0,00), 3$ dengan $4(p=0,05)$ dan 3 dengan $5(p=0,00)$, tetapi tidak didapatkan hubungan yang signifikan antara derajat 4 dan $5(p=0,14)$.

\section{Hubungan antara kadar enzim Glutation Reduktase dengan peningkatan derajat kekeruhan inti lensa pada kelompok usia yang} sama

Grafik 1. Kadar GR antar derajat kekeruhan pada masing-masing kelompok usia

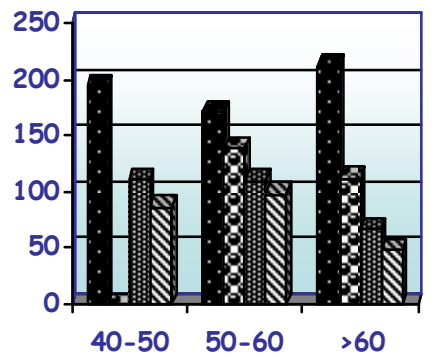

Kelompok usia 40-50 tahun

Tabel 4. Kadar enzim Glutation Reduktase $(\mathrm{mU} / \mathrm{mL})$ kelompok usia 40-50 tahun pada masing-masing derajat kekeruhan inti lensa

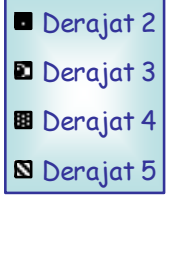

\begin{tabular}{ccccc}
\hline \multirow{2}{*}{ Derajat } & \multirow{2}{\Sigma}{} & \multicolumn{3}{c}{$[\mathrm{GR}](\mathrm{mU} / \mathrm{mL})$} \\
\cline { 3 - 5 } & & Min & Maks & Rata-rata \pm SD \\
\hline 2 & 3 & 178,28 & 213,94 & $195,26 \pm 17,89$ \\
4 & 2 & 102,39 & 120,21 & $111,30 \pm 12,61$ \\
5 & 2 & 76,41 & 96,78 & $86,60 \pm 14,41$ \\
\hline Total & $\mathbf{7}$ & $\mathbf{7 6 , 4 1}$ & $\mathbf{2 1 3 , 9 4}$ & $\mathbf{1 4 0 , 2 3 \pm 5 4 , 0 4}$ \\
\hline
\end{tabular}

$p=0,00$

Tabel 4 menggambarkan kadar enzim Glutation Reduktase pada kelompok usia 40-50 tahun dibandingkan masing-masing derajatnya. Pada kelompok ini tidak didapatkan kekeruhan inti lensa derajat 3. Didapatkan hasil rata-rata kadar enzim Glutation Reduktase yang semakin rendah dengan pertambahan derajat kekeruhan inti lensa. Pada penelitian ini didapatkan hasil yang berbeda nyata dengan $p=0,00$. Pada perbandingan antar derajat, didapatkan hasil berbeda nyata antara derajat 2 dan 4 dengan $p=0,01$ dan antara 2 dan 5 dengan nilai $p=0,00$, sedangkan antara derajat 4 dan 5 tidak berbeda nyata $(p=0,36)$. 
Kelompok usia 50-60 tahun

Tabel 5. Kadar enzim Glutation Reduktase $(\mathrm{mU} / \mathrm{mL})$ kelompok usia 50-60 tahun pada masing-masing derajat kekeruhan inti lensa

\begin{tabular}{ccccc}
\hline \multirow{2}{*}{ Derajat } & \multirow{\Sigma}{*}{} & \multicolumn{3}{c}{$[\mathrm{GR}](\mathrm{mU} / \mathrm{mL})$} \\
\cline { 3 - 5 } & & Min & Maks & Rata-rata $\pm S D$ \\
\hline 2 & 3 & 155,36 & 204,26 & $171,66 \pm 28,23$ \\
3 & 4 & 124,29 & 152,82 & $139,57 \pm 14,36$ \\
4 & 4 & 104,42 & 119,20 & $110,66 \pm 6,17$ \\
5 & 7 & 51,96 & 131,93 & $98,24 \pm 33,75$ \\
\hline Total & $\mathbf{1 8}$ & $\mathbf{5 1 , 9 6}$ & $\mathbf{2 0 4 , 2 6}$ & $\mathbf{1 2 2 , 4 2 \pm 3 6 , 1 8}$ \\
\hline
\end{tabular}

Tabel 5 menggambarkan kadar enzim Glutation Reduktase pada kelompok usia 50-60 tahun dibandingkan masing-masing derajatnya. Didapatkan hasil rata-rata kadar enzim Glutation Reduktase yang semakin rendah dengan pertambahan derajat kekeruhan inti lensa. Pada penelitian ini didapatkan hasil yang berbeda nyata dengan $p=0,01$. Pada perbandingan antar derajat, didapatkan hasil berbeda nyata antara derajat 2 dan 4 dengan $p=0,03$ dan antara 2 dan 5 dengan nilai $p=0,01$, sedangkan antara derajat 2 dan 3 tidak berbeda nyata $(p=0,39)$, begitu pula antara 3 dan

$4(p=0,41), 3$ dan 50,09$)$ serta 4 dan $5(p=0,86)$.

Kelompok usia $>60$ tahun

Tabel 6. Kadar enzim Glutation Reduktase $(\mathrm{mU} / \mathrm{mL})$ kelompok usia >60tahun pada masing-masing derajat kekeruhan inti lensa

\begin{tabular}{ccccc}
\hline \multirow{2}{*}{ Derajat } & \multirow{2}{*}{} & \multicolumn{3}{c}{$[\mathrm{GR}](\mathbf{m U} / \mathbf{m L})$} \\
\cline { 3 - 5 } & 4 & Min & Maks & Rata-rata $\mathbf{S D}$ \\
\hline 2 & 5 & 746,06 & 233,30 & $212,29 \pm 31,82$ \\
3 & 6 & 50,94 & 165,55 & $112,27 \pm 38,88$ \\
4 & 15 & 28,93 & 63,67 & $67,32 \pm 25,47$ \\
5 & $\mathbf{4}, 54 \pm 8,67$ \\
\hline Total & $\mathbf{3 0}$ & $\mathbf{2 8 , 9 3}$ & $\mathbf{2 3 3 , 3 0}$ & $\mathbf{8 4 , 2 5 \pm 6 0 , 1 2}$ \\
\hline
\end{tabular}

Tabel 6 menggambarkan kadar enzim Glutation Reduktase pada kelompok usia $>60$ tahun dibandingkan masing-masing derajatnya. Pada kelompok usia ini juga didapatkan hasil rata-rata kadar enzim Glutation Reduktase yang semakin rendah dengan pertambahan derajat kekeruhan inti lensa. Pada kelompok ini didapatkan hasil yang signifikan dengan $p=0,00$.

Dari hasil perbandingan antar derajat dengan hasil berbeda nyata antara derajat 2 dan $3(p=0,00), 2$ dan $4(p=0,00), 2$ dan $5(p=0,00), 3$ dan $4(p=0,02), 3$ dan $5(p=0,00)$, sedangkan antara derajat 4 dan 5 tidak berbeda nyata $(p=0,29)$.

Hubungan antara kadar enzim Glutation Reduktase dengan meningkatnya kelompok usia pada derajat kekeruhan inti lensa yang sama

Grafik 1. Kadar GR antar kelompok usia pada masing-masing derajat kekeruhan

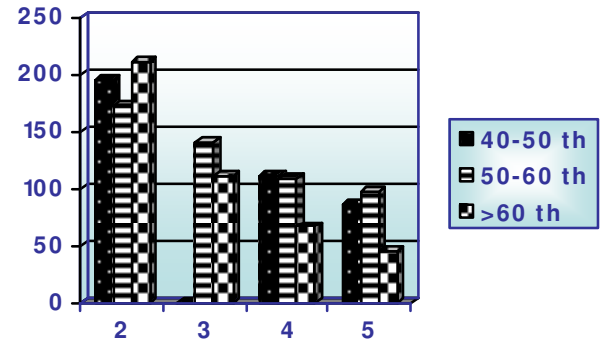

$p=0,22$
Derajat kekeruhan inti lensa 2

Tabel 7. Kadar enzim Glutation Reduktase $(\mathrm{mU} / \mathrm{mL})$ kekeruhan inti lensa derajat 2 pada masing-masing kelompok usia(tahun).

\begin{tabular}{|c|c|c|c|c|}
\hline \multirow{2}{*}{ Usia } & \multirow{2}{*}{$\Sigma$} & \multicolumn{3}{|c|}{$[\mathrm{GR}](\mathrm{mU} / \mathrm{mL})$} \\
\hline & & Min & Maks & Rata-rata $\pm S D$ \\
\hline $40-50$ & 3 & 178,28 & 213,94 & $195,26 \pm 17,89$ \\
\hline $50-60$ & 3 & 155,36 & 204,26 & $171,66 \pm 28,23$ \\
\hline$>60$ & 4 & 166,06 & 233,30 & $212,29 \pm 31,82$ \\
\hline Total & 10 & 155,36 & 233,30 & $194,99 \pm 30,00$ \\
\hline
\end{tabular}

Tabel 7 menggambarkan kadar enzim Glutation Reduktase kekeruhan inti lensa derajat 2 pada masing-masing kelompok usia. Tampak hasil rata-rata kadar enzim Glutation Reduktase yang tidak semakin rendah dengan meningkatnya kelompok usia. Pada penelitian ini tidak didapatkan hubungan yang signifikan $(p=0,22)$.

Pada perbandingan antar kelompok usia didapatkan signifikansi antara kelompok usia 40-50 dan 50-60 sebesar $p=0,57$, kelompok usia 40-50 dan >60 dengan nilai $p=0,71$ dan antara kelompok usia 50-60 dan $>60$ dengan nilai $p=0,20$.

Derajat kekeruhan inti lensa 3

Tabel 8. Kadar enzim Glutation Reduktase $(\mathrm{mU} / \mathrm{mL})$ kekeruhan inti lensa derajat 3 pada masing-masing kelompok usia(tahun).

\begin{tabular}{ccccc}
\hline \multirow{2}{*}{ Usia } & \multirow{2}{*}{$\boldsymbol{\Sigma}$} & \multicolumn{3}{c}{$[\mathrm{GR}](\mathrm{mU} / \mathrm{mL})$} \\
\cline { 3 - 5 } & & Min & Maks & Rata-rata \pm SD \\
\hline $50-60$ & 4 & 124,29 & 152,82 & $139,57 \pm 14,36$ \\
$>60$ & 5 & 74,88 & 165,55 & $112,27 \pm 38,88$ \\
\hline Total & $\mathbf{9}$ & $\mathbf{7 4 , 8 8}$ & $\mathbf{1 6 5 , 5 5}$ & $\mathbf{1 2 4 , 4 0 \pm 3 2 , 2 5}$ \\
\hline
\end{tabular}




$$
\mathrm{p}=0,23
$$

Tabel 8 menggambarkan kadar enzim Glutation Reduktase pada kekeruhan inti lensa derajat 3. Pada derajat ini tidak didapatkan sampel untuk kelompok usia 40-50 tahun. Dari hasil analisa didapatkan kadar enzim Glutation Reduktase pada kekeruhan inti lensa derajat 3 tidak berbeda nyata $(\mathrm{p}=0,23)$.

Derajat kekeruhan inti lensa 4

Tabel 9. Kadar enzim Glutation Reduktase $(\mathrm{mU} / \mathrm{mL})$ kekeruhan inti lensa derajat 4 pada masing-masing kelompok usia(tahun).

\begin{tabular}{ccccc}
\hline \multirow{2}{*}{ Usia } & \multirow{2}{*}{$\boldsymbol{\Sigma}$} & \multicolumn{3}{c}{$[\mathrm{GR}](\mathrm{mU} / \mathrm{mL})$} \\
\cline { 3 - 5 } & & Min & Maks & Rata-rata \pm SD \\
\hline $40-50$ & 2 & 102,39 & 120,21 & $111,30 \pm 12,61$ \\
$50-60$ & 4 & 104,42 & 119,20 & $110,66 \pm 6,17$ \\
$>60$ & 6 & 50,94 & 117,16 & $67,32 \pm 28,47$ \\
\hline Total & $\mathbf{1 2}$ & $\mathbf{5 0 , 9 4}$ & $\mathbf{1 2 0 , 2 1}$ & $\mathbf{8 9 , 1 0 \pm 2 8 , 9 3}$ \\
\hline \multicolumn{2}{c}{} & & & $\mathrm{p}=0,01$
\end{tabular}

Tabel 9 menggambarkan kadar enzim Glutation Reduktase kekeruhan inti lensa derajat 4 pada masing-masing kelompok usia. Dari data diatas didapatkan kadar enzim Glutation Reduktase yang semakin rendah dengan pertambahan kelompok usia. Pada penelitian ini didapatkan hubungan yang signifikan $(\mathrm{p}=0,01)$. Pada perbandingan antar kelompok usia didapatkan hasil signifikan antara kelompok usia 50-60 dan $>60$ dengan nilai $p=0,02$, sedangkan antara kelompok usia 40-50 dan 50-60 dengan nilai $p=1,00$ dan antara kelompok usia 40-50 dan $>60$ dengan nilai $p=0,06$ tidak didapatkan hubungan yang signifikan.

Derajat kekeruhan inti lensa 5

Tabel 10. Kadar enzim Glutation Reduktase $(\mathrm{mU} / \mathrm{mL})$ kekeruhan inti lensa derajat 5 pada masing-masing kelompok usia.

\begin{tabular}{ccccc}
\hline \multirow{2}{*}{ Usia } & \multirow{\Sigma}{*}{$\boldsymbol{\Sigma}$} & \multicolumn{3}{c}{$[\mathrm{GR}](\mathrm{mU} / \mathrm{mL})$} \\
\cline { 3 - 5 } & & Min & Maks & Rata-rata \pm SD \\
\hline $40-50$ & 2 & 76,41 & 96,78 & $86,60 \pm 14,41$ \\
$50-60$ & 7 & 51,96 & 131,93 & $98,24 \pm 33,75$ \\
$>60$ & 15 & 28,93 & 63,67 & $47,54 \pm 8,67$ \\
\hline Total & $\mathbf{2 4}$ & $\mathbf{2 8 , 9 3}$ & $\mathbf{1 3 1 , 9 3}$ & $\mathbf{6 5 , 5 8 \pm 3 0 , 4 5}$ \\
\hline & & & & $\mathrm{p}=0,00$
\end{tabular}

Tabel 10 menggambarkan kadar enzim Glutation Reduktase kekeruhan inti lensa derajat 5 pada masing-masing kelompok usia. Dari data diatas didapatkan kadar enzim Glutation Reduktase yang semakin rendah dengan pertambahan kelompok usia. Pada penelitian ini didapatkan hubungan yang signifikan $(p=0,00)$. Pada perbandingan antar kelompok usia didapatkan hubungan yang signifikan antara kelompok usia 40-50 dan $>60$ dengan nilai $p=0,04$ dan antara kelompok usia 50-60 dan $>60$ dengan nilai $p=0,00$, sedangkan antara kelompok usia 40-50 dan 50-60 tidak didapatkan hubungan yang signifikan dengan nilai $p=0,74$.

\section{PEMBAHASAN}

Penelitian dilakukan di Bagian IImu Penyakit Mata RSU dr Saiful Anwar Malang dan Bagian Biomedik FKUB mulai bulan Agustus 2004-Februari 2006. Distribusi sampel pada penelitian ini kurang merata karena sampel yang diperoleh sangat bergantung pada katarak yang dilakukan ekstraksi dengan indikasi visual. Dari tabel 1 tampak pada kelompok usia 40-50 th hanya didapatkan 7 sampel sehingga estimasi jumlah sampel sebesar 13 setiap kelompok usia tidak dapat dipenuhi. Hal ini menyebabkan power penelitian pada kelompok usia tersebut menurun sampai sekitar $73,2 \%$ dari $80 \%$ yang diperkirakan. 23,24

Data karakteristik pada tabel 1 tersebut juga menunjukkan semakin tua kelompok usia, jumlah penderita katarak semakin banyak dan kekeruhan inti lensa derajat tinggi juga semakin banyak. Hal ini sesuai dengan patogenesa katarak yang akan semakin berat dengan pertambahan usia. Seiring dengan pertambahan usia, berat dan ketebalan lensa meningkat dan daya akomodasi menurun. Lapisan serat yang baru terdorong secara konsentris kearah inti lensa menyebabkan penekanan dan pengerasan (nuclear sclerosis). Protein kristalin lensa berubah secara kimia dan berikatan menjadi molekul protein berat tinggi. Akibat ikatan ini meningkatkan indek refraksi lensa, penyebaran sinar yang masuk dan menurunnya kejernihan. Perubahan kimia pada protein inti lensa ini juga menyebabkan progresifitas pigmentasi. Sehingga lensa menjadi kekuningan atau kecoklatan seiring dengan bertambahnya usia. $10,11,25$

Pada hubungan antara kadar enzim Glutation Reduktase dengan kelompok usia didapatkan kadar yang semakin rendah dengan pertambahan usia (tabel 2), tetapi pada perbandingan antar kelompok usia hanya didapatkan hubungan yang signifikan antara kelompok usia 40-50 dan $>60$ dengan nilai $p=0,04$ dan antara kelompok usia 50-60 dan $>60$ dengan nilai $p=0,05$, sedangkan antara kelompok usia 40-50 dan 50-60 tidak didapatkan hubungan yang signifikan dengan nilai $p=0,73$ ( Tabel 3). Hal ini menunjukkan kadar enzim Glutation Reduktase tidak berbeda nyata antara kelompok 40-50 dan 50-60 tahun, tetapi berbeda nyata pada usia >60 tahun. Hal 
ini kemungkinan berkaitan dengan konsentrasi GSH-3OHKG dan 3OHKG yang berikatan dengan protein mulai meningkat secara cepat setelah dekade ke-5 kehidupan dimana terjadi keadaan biokimia yang memacu proses deaminasi.9,16,21

Pada hubungan antara kadar enzim Glutation Reduktase dengan derajat kekeruhan inti lensa didapatkan kadar yang semakin rendah dengan pertambahan derajat kekeruhan inti (tabel 4). Pada perbandingan antar derajat kekeruhannya didapatkan hubungan yang signifikan antar semua derajat kekeruhan inti lensa, kecuali antara derajat kekeruhan 4 dan 5 (Tabel 5). Hasil yang sama juga didapatkan pada perbandingan antar derajat kekeruhan inti pada kelompok usia 40-50 dan >60 tahun. Belum dapat dijelaskan apakah hal ini menunjukkan kandungan biokimiawi antara derajat kekeruhan 4 dan 5 tidak jauh berbeda. Diperlukan penelitian lebih lanjut untuk memperjelas hal tersebut. Hal ini dapat juga dipengaruhi oleh subyektifitas pada cara pengelompokan derajat kekeruhan inti lensa karena pada derajat 4 dan 5 kekeruhan telah mengenai hampir seluruh inti lensa dan dapat pula disertai kekeruhan kortek sehingga semakin sulit pengelompokan pada kedua derajat ini.

Dari hasil analisa data hubungan antara kadar enzim Glutation Reduktase pada kelompok usia yang sama terhadap derajat kekeruhan inti lensa didapatkan signifikan pada semua kelompok usia, hal ini menunjukkan bahwa kadar enzim Glutation Reduktase semakin rendah dengan pertambahan derajat kekeruhan inti lensa pada kelompok usia yang sama (Tabel 6,8,10). Tetapi perbandingan kadar enzim Glutation Reduktase antar derajat kekeruhannya dalam kelompok usia yang sama didapatkan tidak selalu berbeda nyata $(7,9,11)$, hal ini menunjukkan rata-rata kadar enzim Glutation Reduktase pada satu derajat tidak dapat dijadikan patokan bahwa kadar tersebut menunjukkan derajat tertentu. Dari hasil analisa hubungan antara kadar enzim Glutation Reduktase pada kelompok usia yang sama terhadap derajat kekeruhan inti lensa (Tabel 6,8,10) dapat diinterpretasikan bahwa rendahnya kadar enzim Glutation Reduktase lebih berpengaruh pada peningkatan derajat kekeruhan inti lensa dibandingkan peningkatan kelompok usia. Hal ini tidak sesuai dengan penelitian sebelumnya yang menyebutkan penurunan kadar GSH sesuai dengan peningkatan usia, ${ }^{16}$ tetapi belum didapatkan data penelitian sebelumnya yang menyebutkan adanya hubungan antara kadar GSH dengan derajat kekeruhan inti lensa.

Hubungan antara kadar enzim Glutation Reduktase pada derajat kekeruhan inti lensa terhadap kelompok usia yang berbeda didapatkan bahwa antar masing-masing kelompok usia kadar enzim Glutation Reduktase pada derajat 2 tidak berbeda nyata (Tabel 12). Hal ini kemungkinan karena katarak dengan kekeruhan inti lensa derajat 2 secara klinis dapat juga disertai dengan kekeruhan bagian lensa yang lain misalnya katarak subkapsular atau kortikal. Masih diperlukan penelitian lebih lanjut apakah katarak subkapsular atau kortikal juga dipengaruhi rendahnya kadar enzim Glutation Reduktase. Kesulitan untuk mempelajari hal ini mungkin terhambat oleh teknik operasi ekstra kapsular, sehingga yang dapat diekstraksi adalah bagian inti lensa. ${ }^{26,27}$

Hubungan antara kadar enzim Glutation Reduktase pada derajat kekeruhan inti lensa yang sama terhadap kelompok usia yang berbeda didapatkan hasil pada derajat rendah (2 dan 3) dan kelompok usia muda (40-50 tahun) kadar enzim Glutation Reduktase tidak berbeda nyata. Hal ini menggambarkan terjadinya kekeruhan inti lensa tidak hanya dipengaruhi oleh rendahnya kadar enzim Glutation Reduktase, tetapi kemungkinan juga dipengaruhi oleh faktor yang lain yang berperan pada terjadinya katarak misal genetik, gizi, merokok dan paparan sinar ultraviolet., $, 10,28$

Hubungan yang tidak signifikan pada usia yang muda ( kelompok usia 40-50 dan 50-60) dapat pula menunjukkan bahwa pengaruh enzim Glutation Reduktase kemungkinan lebih berpengaruh pada kelompok usia lebih dari 60 tahun. Hal ini sesuai dengan Bova et al yang menyebutkan penurunan kadar GSH dan peningkatan kadar GSSG sesuai dengan peningkatan usia. ${ }^{16}$ Tetapi adanya angka-angka yang tidak signifikan kemungkinan menunjukkan masih adanya faktor lain yang berpengaruh dalam proses biokimiawi ini.

Kendala pada penelitian ini adalah cara pengelompokan derajat katarak yang masih lebih bersifat subyektif karena keterbatasan alat pemeriksaan. Kendala lain adalah sampel yang sulit dicari karena sampel yang didapat tergantung pada operasi katarak atas indikasi visual, sedang penderita katarak pada usia muda sangat sedikit jumlahnya dan katarak dengan kekeruhan inti yang tipis tidak mungkin dilakukan operasi ekstraksi kecuali disertai kekeruhan bagian lain seperti subkapsular atau kortek. Disamping hal diatas, penelitian ini juga dibatasi oleh waktu.

\section{KESIMPULAN}


